\title{
SEWAGE SLUDGE COMPOST ASSOCIATED TO FREQUENCY OF IRRIGATION FOR Peltophorum dubium (Sprengel) Taubert SEEDLINGS PRODUCTION
}

\author{
Laura Oliveira Cleto da Silva ${ }^{1}$, Aline Cássia da Fonseca ${ }^{1}$, Deicy Carolina Lozano Sivisaca ${ }^{1}$, Magali Ribeiro da \\ Silva²$^{2}$, Roberto Lyra Villas Boas², Iraê Amaral Guerrini² \\ ${ }^{1}$ São Paulo State University (UNESP), Graduate Program in Forestry Science, Botucatu, SP, Brazil - laura.ocleto@ gmail.com, \\ aline_cfonseca@hotmail.com, caroladeicylo@hotmail.com \\ ${ }^{2}$ São Paulo State University (UNESP), Department of Forest, Soil and Environmental Sciences, Botucatu, SP, Brazil - \\ magali.ribeiro@unesp.br,roberto.lyra@unesp.br, irae.guerrini@unesp.br
}

Received for publication: 30/12/2018 - Accepted for publication: 24/06/2019

\begin{abstract}
Resumo
Composto de lodo de esgoto associado à frequência de irrigação para produção de mudas de Peltophorum dubium (Sprengel) Taubert. O descarte inadequado do lodo de esgoto tem se tornado um problema ambiental. Em alguns estados brasileiros, como em São Paulo, seu uso in natura é praticamente proibido devido às exigências restritivas da Resolução CONAMA N 375/2006. Portanto, uma alternativa bastante promissora para reaproveitar esse resíduo é realizar sua compostagem com outros materiais e empregá-lo como substrato na produção de mudas florestais. O objetivo deste estudo foi avaliar o desenvolvimento das mudas de Peltophorum dubium em composto com lodo de esgoto, determinar qual frequência de irrigação seria mais adequada de acordo com as características físicas de cada substrato, e se isso influenciaria nas variáveis morfológicas e nutricionais das mudas. Foram feitos dois compostos: lodo de esgoto compostado com bagaçode-cana e lodo de esgoto compostado com casca de eucalipto, ambos na proporção 1:1. Para controle, utilizouse um substrato comercial. $\mathrm{O}$ experimento foi realizado em esquema fatorial $3 \times 3$ delineamento inteiramente casualizado, sendo três substratos e três frequências de irrigação: duas, três e quatro vezes ao dia. Para aferir o desenvolvimento das mudas, avaliou-se altura, diâmetro de colo, relação altura/diâmetro, massa seca da parte aérea, massa seca radicular, Índice de cor verde, Índice de Qualidade de Dickson, perda de água por lixiviação e água retida no substrato. Os melhores resultados foram observados nas mudas produzidas em composto de lodo de esgoto com casca de eucalipto submetidas às frequências de duas ou três vezes ao dia.

Palavras-chave: Compostagem, canafístula, viveiro florestal, biossólido, água.
\end{abstract}

\begin{abstract}
Inappropriate disposal of sewage sludge has become an environmental problem. In some Brazilian states, such as São Paulo, in natura sewage sludge use is practically prohibited due to restrictive requirements by CONAMA Resolution No. 375/2006. Therefore, a very promising alternative to reuse this residue is to compost it with other materials and use it as a substrate in the production of seedlings. The objective of this study was to evaluate the development of the seedlings of Peltophorum dubium in compost with sewage sludge, to determine which frequency of irrigation would be more adequate according to the physical characteristics of each substrate, and if this would influence the morphological and nutritional variables of the seedlings. Two composts were produced: sewage sludge composted with sugarcane bagasse and sewage sludge composted with eucalyptus bark, both in 1: 1 proportion. Commercial substrate was used for control. This study was completely randomized in a $3 \times 3$ factorial design, which three substrates and three frequencies of irrigation were tested: two, three and four times per day. The evaluated parameters were: plant height, stem diameter ratio, shoot / root ratio, leaf dry mass, root dry mass, total dry mass, green color index, Dickson quality index (IQD), water loss through leaching and substrate water retain capacity. The best results were observed in the seedlings produced in sewage sludge compound with eucalyptus bark submitted to the frequencies of two or three times a day.

Keywords: Composting, canafistula, forest nursery, biosolid, water.
\end{abstract}

\section{INTRODUCTION}

The increase in organic waste is a consequence of population growth added to urbanization. Among these residues, there is sewage sludge, the final waste generated in sewage treatment stations. Its increasing production and inadequate disposal have made this waste an environmental problem. Consisting of organic matter, macro and micronutrients essential for plant development, a very promising and sustainable alternative would be to use sewage sludge as a substrate for the production of forest seedlings, contributing to the preservation of the environment (CABREIRA et al., 2017). 
However, CONAMA Resolution No. 375/2006, current legislation that regulates the use of sewage sludge in Brazil, is still quite strict regarding its use in natura, mainly in the state of São Paulo and Paraná, due to heavy metals and pathogens that this residue may contain (FARIA et al., 2017). Thus, in order for this residue to become suitable for application in the agricultural and forestry area as a substrate and/or organic fertilizer, it is necessary to subject it to a composting process with other structuring and carbon-rich materials (ABREU et al., 2017).

With the growing concern regarding environmental issues, especially regarding environmental restoration, the demand for seedlings of native forest species has also grown (OLIVEIRA et al., 2017).

The species Peltophorum dubium, popularly known as canafistula, was chosen because it presents fast growth and has high economic value, being currently widely used for the recovery of degraded areas. Its wood is considered of quality, moderately heavy (between 0.53 to $0.65 \mathrm{~g} \mathrm{~cm}^{3}$ ), rigid and of long durability, widely used in civil construction, decorations and landscaping, energy production, among others (BERTOLINI et al., 2015). This species shows satisfactory development when cultivated in soils or substrates with good water conditions, but without excess water (GUERRA et al., 1982).

Proper irrigation is essential to form quality seedlings and must be determined according to the chosen species and also with the type of substrate used (SILVA et al., 2012). The water retention capacity of the substrates is directly related to its density and porosity. Substrates based on sewage sludge tend to be denser when compared to commercial substrates, presenting greater water retention capacity (KRATZ, 2013; ABREU et al., 2017).

In forest nurseries, the standardization of irrigation is very common, making it difficult to plan an adequate water management (TATAGIBA et al., 2015). This can result in excessive management, causing the leaching of nutrients, or insufficient management, impairing the plant development (THEBALDI et al., 2016).

In germination phase, seedlings tend to show greater initial development if they receive short-term irrigations, but several times throughout the day, whereas, in growth and rustification phase, seedlings show superior development when they receive long-term irrigations, but a few times a day (WENDLING et al., 2007).

With the growing demand for solutions for organic waste reuse, literature has shown that using composted sewage sludge as a substrate is an excellent alternative, as the compost provides better forest seedlings development. In addition, the most appropriate irrigation depends on the physical characteristics of each substrate, since the water holding capacity of the substrates is directly related to its density.

Therefore, this study aimed to evaluate the quality of the Peltophorum dubium seedlings produced in compounds with sewage sludge, as well as to determine the appropriate irrigation frequency according to the physical characteristics of each substrate.

\section{MATERIAL AND METHODS}

The study was carried out at the Research Seedling Production Nursery, located at the Faculty of Agronomic Sciences, Unesp, Botucatu-SP Campus.

The completely randomized experimental design followed a $3 \times 3$ factorial scheme, containing three substrates (sewage sludge composted with sugarcane bagasse (SSB); sewage sludge composted with eucalyptus bark (SEB) and commercial substrate based on sphagnum peat, vermiculite and roasted rice husk (SC)) and three irrigation frequencies (two, three and four times a day), totaling nine treatments. Each treatment contained four repetitions with 20 seedlings each, totaling 80 seedlings per treatment.

For all treatments, a $12 \mathrm{~mm}$ irrigation blade was fixed, but each treatment received a different irrigation frequency: two (L12F2), three (L12F3) and four times (L12F4) a day. The irrigation schedules were preestablished according to the highest temperatures of the day, being: L12F2 (6 mm at 10 am and $6 \mathrm{~mm}$ at $3 \mathrm{pm})$; L12F3 (4 mm at $10 \mathrm{am}, 4 \mathrm{~mm}$ at $1 \mathrm{pm}$ and $4 \mathrm{~mm}$ at $4 \mathrm{pm}$ ) and L12F4 (3 mm at $10 \mathrm{am}, 3 \mathrm{~mm}$ at $12 \mathrm{pm}, 3 \mathrm{~mm}$ at 2 $\mathrm{pm}$ and $3 \mathrm{~mm}$ at $4 \mathrm{pm}$ ). Each irrigation frequency was arranged in a different bed, totaling three beds.

For substrates preparation, pure sewage sludge, supplied by Sabesp (Basic Sanitation Company of São Paulo State), located at the Faculty of Agronomic Sciences, where composting was also carried out, was used. Two compounds were made: sewage sludge composted with sugarcane bagasse and sewage sludge composted with eucalyptus bark, both in a 1: 1 ratio. The compost was placed in a pile, called a windrow, which was always turned when the mixture exceeded $65^{\circ} \mathrm{C}$. Composting was considered ready when humidity was below $30 \%$ and temperature stabilized. This process took a 45-day period. Then, the compounds were transferred to the nursery. As a witness, a commercial substrate was used. Substrates chemical analysis was performed (Table 1), according to "analytical protocol for chemical characterization of substrate for plants" (Normative Instruction 17, MAPA), to obtain macronutrients and micronutrients available in the substrate solution.

Table 1. Chemical analysis of macronutrients $\left(\mathrm{mg} \mathrm{L}^{-1}\right)$ and micronutrients $\left(\mathrm{mg} \mathrm{L}^{-1}\right)$ available in the substrates solution.

Tabela 1. Análise química dos macronutrientes $\left(\mathrm{mg} \mathrm{L}^{-1}\right)$ e micronutrientes $\left(\mathrm{mg} \mathrm{L}^{-1}\right)$ disponíveis na solução dos substratos. 


\begin{tabular}{ccccccc}
\hline Macronutrients & $\mathbf{N}$ & $\mathbf{P}$ & $\mathbf{K}$ & $\mathbf{C a}$ & $\mathbf{M g}$ & $\mathbf{S}$ \\
\hline $\mathbf{C S}$ & 9 & 1,75 & 13,80 & 2,65 & 1,47 & 6,54 \\
SSB & 16 & 0,51 & 6,70 & 8,40 & 1,21 & 13,77 \\
SEB & 44 & 0,68 & 7,91 & 17,75 & 1,57 & 29,27 \\
\hline Micronutrients & $\mathbf{N a}$ & $\mathbf{B}$ & $\mathbf{C u}$ & $\mathbf{F e}$ & $\mathbf{M n}$ & $\mathbf{Z n}$ \\
\hline CS & 9,24 & 0,06 & 0,02 & 0,15 & 0,02 & 0,01 \\
SSB & 9,22 & 0,06 & 0,02 & 0,29 & 0,05 & 0,05 \\
SEB & 10,09 & 0,08 & 0,01 & 0,94 & 0,10 & 0,07 \\
\hline
\end{tabular}

CS: commercial substrate based on peat, vermiculite and roasted rice husk; SSB: sewage sludge composted with sugarcane bagasse; SEB: sewage sludge composted with eucalyptus bark.

Peltophorum dubium seeds were collected at the Lageado - Unesp farm, also located in the city of Botucatu-SP. Before sowing, the seeds were submitted to dormancy overcoming process in hot water at $92{ }^{\circ} \mathrm{C}$, according to the methodology described by Dutra et al. (2013). Then, the seeds were sown in $110 \mathrm{~cm}$ tubes already filled with the substrates, and then the tubes were taken to the bed with $50 \%$ shade, where they remained for approximately 60 days for germination, until the formation of seedlings. After this period, the tubes were transferred to the beds covered with 150 micron light diffuser plastic, and stored in their respective treatments. In total, there were nine treatments. Each of the three beds contained twelve trays, four trays per substrate, 20 seedlings per tray, thus totaling 80 seedlings per substrate, 240 seedlings per bed and 720 seedlings in total.

The experiment was completed 150 days after sowing, and the following analyzes were carried out to measure seedling quality: height $(\mathrm{H})$ in centimeters, with the aid of a graduated ruler; diameter at root collar (DRC) in millimeters, with the aid of a digital caliper; height and diameter ratio (H/D); Green color index (GCI), using the SPAD chlorophyll meter, capable of measuring the $\mathrm{N}$ content in the leaves; dry mass of the aerial part (DMAP), root dry mass (RDM) and total dry mass (TDM), obtained in an oven at a temperature of $65^{\circ} \mathrm{C}$, until reaching constant weight; Dickson's Quality Index (DQI) using the formula described by Dickson et al. (1960); water retained in the substrate and water loss by leaching, following the methodology used by Lea-Cox et al. (2001), in which plastic bags attached with rubber bands are placed in the tubes, weighing them before and after irrigation, and the water weight that left the tube bottom and the amount stored in the plastic bags is discounted.

The data were submitted to the assumption of normality verification test Shapiro-Wilk. Then, Analysis of Variance (ANOVA) was performed to compare the effects of each treatment on the variables analyzed and, when there was a significant difference at the level of 5\% probability, the data were subjected to the Scott-Knott test $(\mathrm{p}<0.05)$ to compare the means.

\section{RESULTS}

The seedlings produced in the commercial subtract and in the sludge compost with eucalyptus bark showed the best growth characteristics when compared to the seedlings produced in the sludge compost with sugarcane bagasse. As for the irrigation frequencies, the seedlings submitted to the frequencies of two and three times a day showed higher averages in relation to the frequency of four times a day.

In the physical analysis of the substrates (Table 2), it is observed that the SEB substrate exhibited the highest percentage in microporosity, demonstrating to be a more retaining material, while the SSB substrate had the highest percentage in macroporosity, and therefore, more draining.

Table 2. Physical analysis of the substrates: total porosity (TP), macroporosity (\%), microporosity (\%) and water retention capacity (WR).

Tabela 2. Análise física dos substratos: porosidade total (PT), macroporosidade (\%), microporosidade (\%) e capacidade de retenção de água (RA).

\begin{tabular}{ccccc}
\hline Substrates & TP $(\%)$ & Macro (\%) & Micro (\%) & WR (ml) \\
\hline CS & $79.3 \mathrm{a}$ & $36.2 \mathrm{~b}$ & $43.1 \mathrm{~b}$ & $22.4 \mathrm{~b}$ \\
SSB & $79.2 \mathrm{a}$ & $41.5 \mathrm{a}$ & $37.7 \mathrm{c}$ & $19.6 \mathrm{c}$ \\
SEB & $75.9 \mathrm{~b}$ & $24.6 \mathrm{c}$ & $51.2 \mathrm{a}$ & $26.6 \mathrm{a}$ \\
\hline CV\% & $1,79 \%$ & $8,58 \%$ & $5,71 \%$ & $5,85 \%$ \\
\hline
\end{tabular}

CS: commercial substrate based on peat, vermiculite and roasted rice husk; SSB: sewage sludge composted with sugarcane bagasse; SEB: sewage sludge composted with eucalyptus bark. 
The variables amount of water retained in the substrates and water loss by leaching (Table 3) were analyzed together with the data obtained in the substrates physical analysis.

Regarding the water retained in the substrate, at irrigation frequencies of two and three times a day, there was no statistical difference between the means of water retained in the substrates. At the frequency of four times a day, substrates SSB and SEB retained a greater amount of water compared to the commercial substrate. All substrates showed greater water retention at a frequency of twice a day.

Regarding the variable amount of water lost by leaching, SSB substrate showed the highest water loss, and SEB substrate, the lowest loss, reflecting the percentage of macro and microporosity of each substrate. Substrates CS and SSB showed the highest water loss in the irrigation frequency twice a day, while the other irrigation frequencies showed lower and similar means. For SEB, the frequency of irrigation did not influence the loss of water by leaching.

Table 3. Water retained in the substrates after irrigation and water loss by leaching.

Tabela 3. Água retida nos substratos após irrigação e perda de água por lixiviação.

\begin{tabular}{cccc}
\hline Water retained in the substrate $(\mathrm{g})$ & \multicolumn{3}{c}{ Irrigation frequencies } \\
\hline Substrates & $\mathrm{F} 2$ & $\mathrm{~F} 3$ & $\mathrm{~F} 4$ \\
\hline $\mathrm{CS}$ & $5.8 \mathrm{Aa}$ & $3.3 \mathrm{Ab}$ & $2.7 \mathrm{Bb}$ \\
$\mathrm{SSB}$ & $5.1 \mathrm{Aa}$ & $3.7 \mathrm{Ab}$ & $3.7 \mathrm{Ab}$ \\
$\mathrm{SEB}$ & $6.4 \mathrm{Aa}$ & $3.0 \mathrm{Ac}$ & $4.2 \mathrm{Ab}$ \\
\hline CV 17.3\% & \multicolumn{5}{c}{ Irrigation frequencies } \\
\hline Loss of water by leaching $(\mathrm{g})$ & $\mathrm{F} 2$ & $\mathrm{~F} 3$ & $\mathrm{~F} 4$ \\
\hline Substrates & $6.0 \mathrm{Ba}$ & $3.6 \mathrm{Ab}$ & $3.3 \mathrm{Ab}$ \\
\hline CS & $7.2 \mathrm{Aa}$ & $4.0 \mathrm{Ab}$ & $3.9 \mathrm{Ab}$ \\
SSB & $3.7 \mathrm{Ca}$ & $4.1 \mathrm{Aa}$ & $4.3 \mathrm{Aa}$ \\
\hline SEB & \multicolumn{3}{c}{}
\end{tabular}

Means followed by equal capital letters in the column, within each variable, and lowercase letters in the line do not differ statistically by the Scott-Knott test $(p<0.05)$.

Regarding height (Table 4), the analysis of variance (ANOVA) showed interaction between the factors. Among all the substrates, SEB compound provided the greatest Peltophorum dubium seedlings growth, regardless of irrigation frequencies, although the seedlings produced in commercial substrate, in the three-times a day frequency, presented a statistically similar average. Seedlings produced on commercial substrate showed greater growth in height when submitted to two and three times a day frequencies, while the compounds SSB and SEB promoted greater seedlings height when submitted to the twice a day irrigation frequency.

Table 4. Height (cm) of Peltophorum dubium seedlings subjected to irrigation frequencies and substrates, 150 days after sowing.

Tabela 4. Altura $(\mathrm{cm})$ das mudas de Peltophorum dubium submetidas às frequências de irrigação e aos substratos, 150 dias após a semeadura.

\begin{tabular}{cccc}
\hline & \multicolumn{3}{c}{ Irrigation frequencies } \\
Substrates & $\mathrm{F} 2$ & $\mathrm{~F} 3$ & $\mathrm{~F} 4$ \\
\hline $\mathrm{CS}$ & $20.4 \mathrm{Ba}$ & $21.2 \mathrm{Aa}$ & $18.2 \mathrm{Bb}$ \\
$\mathrm{SSB}$ & $21.0 \mathrm{Ba}$ & $18.8 \mathrm{Bb}$ & $18.2 \mathrm{Bb}$ \\
$\mathrm{SEB}$ & $25.5 \mathrm{Aa}$ & $22.3 \mathrm{Ab}$ & $20.5 \mathrm{Ac}$ \\
\hline $\mathrm{CV} 23.6 \%$ & &
\end{tabular}

Means followed by equal capital letters in the column, within each variable, and lowercase letters in the line do not differ statistically by the Scott-Knott test $(p<0.05)$

For the diameter at root collar variable (Table 5), according to ANOVA, there was no interaction between the substrate factors and irrigation frequencies at $5 \%$ probability level, however the data differed statistically when analyzed separately. SEB substrate provided the largest diameters at root collar to the canafistula seedlings. The 
seedlings submitted to two and three times irrigation frequencies showed greater diameter at root collar development, presenting higher averages in relation to the four times a day frequency.

Table 5. Diameter at root collar (mm) of Peltophorum dubium seedlings subjected to irrigation frequencies and substrates, 150 days after sowing.

Tabela 5. Diâmetro de colo (mm) das mudas de Peltophorum dubium submetidas às frequências de irrigação e aos substratos, 150 dias após a semeadura.

\begin{tabular}{cc}
\hline Substrates & Diameter at Root Collar (mm) \\
\hline CS & $5.6 \mathrm{~b}$ \\
SSB & $5.5 \mathrm{~b}$ \\
SEB & $6.5 \mathrm{a}$ \\
\hline Irrigation frequencies & $5.9 \mathrm{a}$ \\
F2 & $6.0 \mathrm{a}$ \\
F3 & $5.7 \mathrm{~b}$ \\
\hline
\end{tabular}

CV $13.1 \%$

Means followed by equal capital letters in the column, within each variable, and lowercase letters in the line do not differ statistically by the Scott-Knott test $(p<0.05)$.

According to ANOVA, there was an interaction between the factors for the height/diameter variable (Table 6). At the twice a day irrigation frequency, seedlings produced in SEB showed the highest average in the height/diameter ratio, while at the three times a day frequency, the highest average was obtained by the seedlings produced in CS. In the frequency of four times a day, in turn, all averages were similar to each other. The averages obtained by the seedlings produced in CS were similar to each other for all irrigation frequencies, however both compounds with sludge provided the seedlings with superior averages only at the twice a day frequency.

Table 6. Height/diameter ratio (H/D) ratio of Peltophorum dubium seedlings submitted to irrigation frequencies and substrates, 150 days after sowing.

Tabela 6. Relação altura/diâmetro (H/D) das mudas de Peltophorum dubium submetidas às frequências de irrigação e aos substratos, 150 dias após a semeadura.

\begin{tabular}{cccc}
\hline & \multicolumn{3}{c}{ Irrigation frequencies } \\
Substrates & F2 & F3 & F4 \\
\hline CS & $3.6 \mathrm{Ba}$ & $3.7 \mathrm{Aa}$ & $3.4 \mathrm{Aa}$ \\
SSB & $3.9 \mathrm{Ba}$ & $3.4 \mathrm{Bb}$ & $3.5 \mathrm{Ab}$ \\
SEB & $4.0 \mathrm{Aa}$ & $3.4 \mathrm{Bb}$ & $3.3 \mathrm{Ab}$ \\
\hline
\end{tabular}

Means followed by equal capital letters in the column, within each variable, and lowercase letters in the line do not differ statistically by the Scott-Knott test $(p<0.05)$

The Green Color Index shows the N (nitrogen) content, obtained by SPAD, in the Peltophorum dubium seedlings leaves (Table 7). For this variable, according to ANOVA, only the substrate factor differed at the 5\% probability level, and the irrigation frequencies did not influence the $\mathrm{N}$ content in the leaves. The seedlings produced on SEB substrate had the highest $\mathrm{N}$ content in the aerial part, when compared to the seedlings produced on the other substrates. CS and SSB substrate, in turn, had lower and similar means.

Table 7. Green Color Index (G.C.I) for evaluation of N (nitrogen) content in leaves of Peltophorum dubium, 150 days after sowing.

Tabela 7. Índice de Cor Verde (I.C.V.) para avalição do teor de N (nitrogênio) nas folhas de Peltophorum dubium, 150 dias após a semeadura. 


\begin{tabular}{cc}
\hline Substrates & G.C.I \\
\hline CS & $24.3 \mathrm{~b}$ \\
SSB & $23.8 \mathrm{~b}$ \\
SEB & $26.2 \mathrm{a}$ \\
\hline
\end{tabular}

$$
\mathrm{CV}=29.3 \%
$$

Means followed by equal capital letters in the column, within each variable, and lowercase letters in the line do not differ statistically by the Scott-Knott test $(p<0.05)$

There was no interaction between the substrate factors and irrigation frequencies at the 5\% probability level for the variables dry mass of the aerial part (DMAP), root dry mass (RDM), total dry mass (TDM) and Dickson's Quality Index (DQI), as can be seen in Table 8.

Seedlings grown in SEB compost produced the largest amounts of biomass in the aerial part and in the root part, providing the highest averages for the three variables analyzed.

Regarding the irrigation frequencies, the seedlings that received the two and three times a day frequencies also produced the largest amounts of biomass for the three variables. SSB substrate at the frequency of four times a day provided the seedlings with the lowest biomass production for all variables.

As for the Dickson Quality Index (DQI), the seedlings produced in SEB compost presented the best quality in comparison to the seedlings produced in the other substrates, while the seedlings submitted to the three times a day frequency showed the best quality in relation to the others irrigation frequencies.

Table 8. Dry mass of the aerial part (DMAP), root dry mass (RDM), total dry mass (TDM), in grams (g) and Dickson Quality Index (DQI) of the Peltophorum dubium seedlings, 150 days after sowing.

Tabela 8. Massa seca aérea (MSA), massa seca radicular (MSR), massa seca total (MST) em gramas (g) e Índice de Qualidade de Dickson (IQD) das mudas de Peltophorum dubium, 150 dias após a semeadura.

\begin{tabular}{ccccc}
\hline Substrates & DMAP & RDM & TDM & DQI \\
\hline CS & $4.0 \mathrm{~b}$ & $1.4 \mathrm{~b}$ & $5.4 \mathrm{~b}$ & $0.82 \mathrm{~b}$ \\
SSB & $3.7 \mathrm{c}$ & $1.3 \mathrm{c}$ & $4.9 \mathrm{c}$ & $0.80 \mathrm{c}$ \\
SEB & $5.1 \mathrm{a}$ & $1.8 \mathrm{a}$ & $6.9 \mathrm{a}$ & $1.08 \mathrm{a}$ \\
\hline Irrigation & & & & \\
frequencies & DMAP & RDM & TDM & DQI \\
\hline F2 & $4.5 \mathrm{a}$ & $1.5 \mathrm{a}$ & $6.0 \mathrm{a}$ & $0.89 \mathrm{c}$ \\
F3 & $4.4 \mathrm{a}$ & $1.6 \mathrm{a}$ & $6.0 \mathrm{a}$ & $0.98 \mathrm{a}$ \\
F4 & $3.9 \mathrm{~b}$ & $1.3 \mathrm{~b}$ & $5.3 \mathrm{~b}$ & $0.84 \mathrm{~b}$ \\
CV\% & $23,3 \%$ & $29,5 \%$ & $22,8 \%$ & $32,4 \%$
\end{tabular}

Means followed by equal capital letters in the column, within each variable, and lowercase letters in the line do not differ statistically by the Scott-Knott test $(p<0.05)$.

\section{DISCUSSION}

In this study, the sewage sludge compound with eucalyptus bark (SEB) submitted to the $12 \mathrm{~mm}$ blade, at irrigation frequencies two and three times a day, proved to be the most suitable substrate for the production of Peltophorum dubium (canafístula) seedlings, benefiting most of the morphological and nutritional variables analyzed. SSB compound, however, even containing sewage sludge in its composition, produced seedlings with the lowest averages for all parameters analyzed, regardless of the frequency of irrigation.

Commercial substrate (CS), in turn, is an inert material, produced specifically to provide firm clods and absorb the amount of water and nutrients in the ideal proportion.

It is observed in the chemical analysis that the SEB compound showed the highest concentrations for most of the nutrients found, with the exception of $\mathrm{P}, \mathrm{K}$ and $\mathrm{Cu}$. The commercial substrate, however, presented low concentrations of nutrients, a common characteristic to commercial substrates (GUERRINI and TRIGUEIRO, 2004). However, it presented the highest concentrations of $P$ and $K$. This can be explained by the fact that the batch of commercial substrate used in this experiment was enriched with simple superphosphate still in its 
production process. In addition, the commercial substrate contained rice husk in its composition, a material rich in K.

Regarding the physical analysis of the substrates, the pattern established by Guerrini and Trigueiro (2004) indicates that SEB was the only substrate that fit the ideal range of microporosity, reflecting on a more retaining substrate. As suggested by Kratz et al., (2013), substrates that contain sewage sludge in their composition are usually denser than commercial substrates. Seedlings produced in SEB compound showed higher averages for all variables analyzed. During composting, the fragments of eucalyptus bark decomposed, forming fine particles, making this material denser in relation to the others. The density of the substrates is directly related to its porosity, reflecting on its water retention capacity, macro and micronutrients quantity, available water and electrical conductivity (ABREU et al., 2017). The characteristics of SEB made this substrate present water and nutrients retention in an adequate amount for the canafistula seedlings development, in addition to providing firm and well aggregated clods. CS and SSB substrate, in turn, fell within the ideal range of macroporosity. The seedlings produced on SSB substrate had the lowest averages for all variables analyzed. The sugarcane bagasse fibers made this material porous, not able to retain water and nutrients in the amount that the Peltophorum dubium seedlings required.

The variables amount of water retained in the substrates and water loss by leaching (Table 3) can be analyzed together with the data obtained in the substrates physical analysis. SEB substrate, having the highest percentage in microporosity $(51.2 \%)$, was the substrate that had the lowest loss and the highest water retention capacity $(26.6 \%)$ compared to the other substrates. However, SSB was the substrate with the greatest loss and the lowest water retention capacity $(19.6 \%)$, due to its percentage in macroporosity $(41.5 \%)$.

All substrates showed greater water loss at the twice a day frequency. These data corroborate the results found by Delgado et al. (2017), in which the authors, testing irrigation frequencies of two and four times a day for Inga vera production, observed that the substrate used also lost a greater amount of water in the twice a day frequency, once the irrigation of this frequency was of longer duration, causing the water to penetrate all the substrate, reaching the bottom of the tube. However, as the four times a day frequency was shorter, the water was restricted to the substrate surface in the tube. The authors suggest that the seedlings growth subjected to the four times a day frequency was also lower, since only the tube surface was humidified.

As observed in this study, Delgado et al. (2017) also found that seedlings produced under the twice a day irrigation frequency showed greater growth in height, diameter at root collar, H/D ratio and dry mass. Also according to the authors, irrigation twice a day managed to reach the deepest levels of the root ball in the tube, irrigating the entire root system, providing a greater amount of water for the seedlings.

Still in relation to seedlings growth, SEB substrate, subjected to the two and three times a day frequencies, provided the formation of canafistula seedlings with the highest averages in height, diameter at root collar and height/diameter ratio. According to Gonçalves et al. (2000), native species seedlings must have a height between 20 to $35 \mathrm{~cm}$. Thus, with the exception of seedlings produced on SSB substrate at the three and four times a day frequencies, and of the seedlings produced in CS, at the four times a day frequency, the other treatments produced seedlings with the height within the average suggested by these authors. Cabreira et al. (2017) observed that seedlings of three species native to the Atlantic Forest (Peltophorum dubim, Lafoensia pacari and Ceiba speciosa), produced in sewage sludge compound with pine bark, showed greater growth in height as it increased the volumetric proportion of sewage sludge in the substrate. The authors state that seedlings produced in composted sewage sludge reach the rusting period more quickly compared to seedlings produced in commercial substrate.

As for the diameter at root collar, Gonçalves et al. (2000) established that native seedlings must have a diameter at root collar between 5 to $10 \mathrm{~mm}$ so that they can be taken to the field. In this study, all treatments produced seedlings with a diameter at root collar within the range suggested by the authors, however, SEB substrate provided the highest averages for this variable. These results corroborate the data obtained by Scheer $e t$ al. (2012), who found that the seedlings of Lafoensia pacari presented larger diameters at root collar when produced in sewage sludge composted with tree pruning in the proportions $3: 1$ and 2: 1, in comparison to the commercial substrate used as control.

The H/D ratio expresses the plant's growth balance, as it relates the two variables in just one. According to José et al., (2005), the value of the H/D ratio must be less than 10. Thus, all treatments produced seedlings with values within the average suggested by the authors.

The analysis of the Green Color Index, carried out through the SPAD chlorophyll meter, showed that the Peltophorum dubium seedlings produced in SEB had the highest $\mathrm{N}$ content in their leaves, in comparison to the seedlings produced in the other substrates. During the plant growth process, $\mathrm{N}$ moves to the youngest leaves, as it is an element with high mobility, therefore plants with greater growth in height may have low $\mathrm{N}$ content, since it was used for their growth, causing the "dilution effect" (SENA JÚNIOR et al., 2008; SANT'ANA et al., 2010). However, in this study, seedlings produced with SEB substrate, in addition to presenting greater growth in height, also showed the highest concentration of $\mathrm{N}$ in their leaves.

FLORESTA, Curitiba, PR, v. 50, n. 2, p. 1389 - 1398, abr/jun 2020.

Silva, L. O. C. et.al. 
Trigueiro and Guerrini (2014) found that the Schinus terebinthifolius seedlings showed greater growth in height when produced in sewage sludge with carbonized rice husk compared to commercial substrate. The authors attributed the higher seedling growth to the amount of nitrogen available in the sludge, in contrast to commercial substrates that usually have a low nutrient content.

For dry mass of the aerial part (DMAP), root dry mass (RDM) and total dry mass (TDM), the seedlings produced with SEB showed the highest biomass production for the three variables. As suggested by Cavalcante $e t$ al., (2016), the greater the biomass production of the aerial part, the greater the photosynthetic potential, guaranteeing the seedlings greater growth. However, the seedlings produced in SSB, in turn, had the lowest production of biomass.

The root dry mass has been considered by several authors as one of the most efficient variables for determining the quality of seedlings, since a well-formed root system guarantees greater seedling survival in the field and resistance to bush competition, in addition to greater water and nutrients absorption (GOMES and PAIVA, 2011). This could also be observed in the roots of the seedlings produced with SEB, as they presented the highest averages for this variable, demonstrating greater production of root biomass. In addition, well-developed roots and added to the substrate facilitate the removal of the root ball from the tube, preserving its shape for better planting in the field (WENDLING et al., 2007).

The Dickson Quality Index (DQI) is an important indicator of plant quality, as it covers the main variables: height, diameter at root collar and dry mass. According to Caldeira et al., (2012) the higher the DQI value, the better the seedling quality. For this variable, SEB substrate and the three times a day irrigation frequency provided seedlings with the highest averages, that is, seedlings with the best quality among all treatments.

\section{CONCLUSION}

- The greatest growth and best quality of the Peltophorum dubium seedlings were produced in the compost of sewage sludge with eucalyptus bark (SEB) in the proportion 1:1, associated with the two and three times a day irrigation frequencies. The sewage sludge composted with sugarcane bagasse (SSB) showed the formation of seedlings with the lowest averages and inferior quality.

\section{ACKNOWLEDGMENTS}

To CNPq (National Council for Scientific and Technological Development) for the scholarship granted; to FAPESP (São Paulo Research Foundation) and SABESP (Basic Sanitation of São Paulo State Company) for funding the Project "Composting of Sewage Sludge: evaluation of the process, the product generated and costs", which this research makes part, from FAPESP/SABESP Edital (PITE-Partnership for Technological Innovation Program, Process 2013/50413-0). To all the members team, and for being part of this project and this team.

\section{REFERENCES}

ABREU, A. H. M.; LELES, P. S. S.; MELO, L. A.; OLIVEIRA, R. R.; FERREIRA, D. H. A. A. Caracterização e potencial de substratos formulados com biossólido na produção de mudas de Schinus terebinthifolius Raddi e Handroanthus heptaphyllus (Vell) Mattos. Ciência Florestal, Santa Maria, v. 27, n.4, 2017.

BERTOLINI, I. C.; DEBASTIANI, A. B.; BRUN, E. J. Caracterização silvicultural da canafístula (Peltophorum dubium (Sprengel) Taubert) Scientia Agraria Paranaensis, Marechal Cândido Rondon, v. 14, n. 2, p. 67-76, 2015.

CALDEIRA, M. V. W.; DELARMINA, W. M.; LÜBE, S. G.; GOMES, D. R.; GONÇALVES, E. O.; ALVES, A. F. Biossólido na composição de substrato para a produção de mudas de Tectona grandis. Floresta, Curitiba, v. 42 , n. 1, p. $77-84,2012$.

CABREIRA, G. V.; LEleS, P. S. S.; AlOnSO, J. M.; ABREU, A. H. M.; LOPES, N. F.; SANTOS, G. R. Biossólido como componente de substrato para produção de mudas florestais. Floresta, Curitiba, v. 47, n. 2, p. 165 - 176, 2017.

CAVAlCANTE, A. L. G.; OlIVERIA, F. A.; PEREIRA, K. T. O.; DANTAS, R. P.; OLIVEIRA, M. K. T.; CUNHA, R. C.; SOUZA, M. W. L. Desenvolvimento de mudas de mulungu fertirrigadas com diferentes soluções nutritivas. Floresta, Curitiba, v. 46, n. 1, p. 47-55, 2016. 
DELGADO, L. G. M.; SILVA, R. B. G.; SILVA, M. R. Qualidade morfológica de mudas de ingá sob diferentes manejos hídricos. Irriga, Botucatu, v. 22, n. 3, p. 420-429, julho-setembro, 2017.

DICKSON, A.; LEAF, A. L.; HOSNER, J. F. Quality appraisal of white spruce and white pine seedling stock in nurseries. The Forestry Chronicle, Mattawa, v. 36, n. 1, p. 10-13, 1960.

DUTRA, T. R.; MASSAD, M. D.; SARMENTO, M. F. Q.; OLIVEIRA, J. C. Substratos alternativos e métodos de quebra de dormência para produção de mudas de canafístula Revista Ceres, Viçosa, v. 60, n.1, p. 072-078, 2013.

FARIA, M. F.; GUERRINI, I. A.; OLIVEIRA, F. C.; SATO, M. I. Z.; HACHICH, E. M.; PASSOS, J. R. S.; GOULART, L. M. L.; SILVA, T. T. S.; GAVA, J. L.; FURCHES, J. C.; JAMES, J.; HARRISON, R. B. Persistence of Ascaris spp. ova in tropical soil cultivated with Eucalyptus and fertilized with municipal biosolids. Journal of Environmental Quality, Madison, v. 46, n. 3, p. 522-527, 2017.

GOMES, J.M.; PAIVA, H.N. Viveiros florestais: propagação sexuada. Editora UFV - Viçosa, MG. Série didática, 2011, 116p.

GONÇALVES J. L. M.; SANTERELLI E. G.; NETO S. P. M.; MANARA M. P. Produção de mudas de espécies nativas: substrato, nutrição, sombreamento e fertilização. In: Nutrição e fertilização florestal, IPEF, 2000.

GUERRA, M. P.; NODARI, R. O.; REIS, A.; GRANDO, J. L. Comportamento da canafístula (Peltophorum dubium (Sprengel) Taubert) em viveiro, submetida a diferentes métodos de quebra de dormência e semeadura. Boletim de Pesquisa Florestal, Colombo, n. 5, p. 1-18, 1982.

GUERRINI, I. A.; TRIGUEIRO, R. M. Atributos físicos e químicos de substratos. Compostos por biossólidos e casca de arroz carbonizada. Revista Brasileira de Ciência do Solo, Viçosa, v. 28, p. 1069-1076, 2004.

JOSÉ, A. C.; DAVIDE, A. C.; OLIVEIRA, S. L. Produção de mudas de aroeira (Schinus terebinthifolius Raddi) para recuperação de áreas degradadas pela mineração de bauxita. Revista Cerne, Lavras. v. 11, n. 12 , p. 187 $196,2005$.

KRATZ, D.; WENDLING, I.; NOGUEIRA, A.C.; SOUZA, V. Propriedades físicas e químicas de substratos renováveis. Revista Árvore, Viçosa, v. 37, n. 6, p. 1103-1113, 2013.

LEA-COX, J. D.; ROSS, D. S.; TEFFEAU, K. M. A water and nutrient management planning process for container nursery and greenhouse production systems in Maryland. Journal of Environmental Horticulture, Columbus, v. 19, n. 4 , p. 226-229, 2001.

OliVEIRA, C. D. C.; GONZAGA, L. M.; CARVAlHO, J. S.; MELO, L. A.; DAVIDE, A. C.; BOTELHO, S. A. Riqueza de mudas de espécies florestais nativas potencialmente produzidas na Bacia do Rio Grande, MG. Pesquisa Florestal Brasileira, Colombo, v. 37, n. 90, p. 159-170, 2017.

SANT’ANA, E. V. P.; SANTOS, A. B.; SILVEIRA, P. M. Adubação nitrogenada na produtividade, leitura e spad e teor de nitrogênio em folhas de feijoeiro. Pesquisa Agropecuária Tropical, Goiânia, v. 40, n. 4, p. 491-496, 2010 .

SCHEER, M. B.; CARNEIRO, C.; BRESSAN, O. A.; SANTOS, K. G. Crescimento e Nutrição de Mudas de Lafoensia pacari com Lodo de Esgoto. Floram, Rio de Janeiro, v. 19, n. 1, p. 55-65, 2012.

SENA JÚNIOR, J. A.; BARBOSA, L. H. A.; CASAROLI, D.; EVANGELISTA, A. W. P.; COSTA, F. R. Crescimento de mogno africano submetido a diferentes níveis de irrigação por microaspersão. Irriga, Botucatu, v. 21, n. 3, p. $466-480,2016$.

SILVA, R. B. G.; SIMÕES, D.; SILVA, M. R. Qualidade de mudas clonais de Eucalyptus urophylla x E. grandis em função do substrato. Revista Brasileira de Engenharia Agrícola e Ambiental, Campina Grande, v. 16, n. 3, p. 297-302, 2012.

TATAGIBA, S. D.; XAVIER, T. M. T.; TORRES, H.; PEZZOPANE, J. E. M.; CECÍlIO, R. A.; ZANETTI, S. S. Determinação da máxima capacidade de retenção de água no substrato para produção de mudas de eucalipto em viveiro. Floresta, Curitiba, v. 45, n. 4, p. 745-754, 2015. 
THEBALDI, M. S.; LIMA, L. A.; SILVA, L. A. C.; COLARES, M. F. B.; LIMA, P. L. T. Eficiência de sistemas de irrigação em mudas de espécies florestais nativas produzidas em tubetes. Ciência Florestal, Santa Maria, v. 26, n. 2, p. 401-410, 2016.

TRIGUEIRO, R. M.; GUERRINI, I. A. Utilização de lodo de esgoto na produção de mudas de aroeira-pimenteira. Revista Árvore, Viçosa, v. 38, n. 4, p. 657-665, 2014.

WENDLING, I.; GUASTALA, D.; DEDECEK, R. Características físicas e químicas de substratos para produção de mudas de Ilex paraguariensis St. Hil. Revista Árvore, Viçosa, v. 31, n.2, p. 209-220, 2007. 